\title{
Vedolizumab-Induced Liver Injury
}

\author{
Miguel Mascarenhas Saraiva ${ }^{a}$ Tiago Ribeiro $^{a}$ Emanuel Dias $^{a}$ \\ Joanne Lopes Lopes ${ }^{b, c}$ Hélder Cardoso ${ }^{a, c}$ Guilherme Macedo ${ }^{a, c}$ \\ ${ }^{a}$ Gastroenterology Department, Centro Hospitalar Universitário de São João, Porto, Portugal; b Pathology \\ Department, Centro Hospitalar de São João, Porto, Portugal; ' ${ }^{C}$ Faculty of Medicine of the University of Porto, \\ Porto, Portugal
}

\section{Keywords}

Vedolizumab · Acute liver injury · Hepatotoxicity ·

Drug-induced liver injury $\cdot$ Inflammatory bowel disease

\section{Abstract}

Drug-induced liver injury is an important cause of acute liver injury. Immunomodulatory therapies, such as vedolizumab (VDZ), are being increasingly used for the treatment of several diseases, most importantly inflammatory bowel disease. Several studies have demonstrated the safety of this substance. To date, only one post-marketing study has reported a case of hepatotoxicity attributable to VDZ. The authors present the case of a 41-year-old woman followed at the gastroenterology outpatient clinic for ulcerative colitis (UC) and autoimmune hepatitis (AIH). This patient was being treated with low-dose glucocorticoids for AlH (prednisolone $10 \mathrm{mg}$ ), with adequate disease control. Additionally, she was being treated with oral salicylates (mesalamine $3 \mathrm{~g} /$ day) and oral budesonide ( $9 \mathrm{mg} /$ day) for her UC. For uncontrolled UC, she was started on VDZ. Two weeks after the first infusion of VDZ, the patient developed a clinical and analytical phenotype compatible with acute hepatitis. Diagnostic workup for causes of hepatocellular liver injury retrieved no results. A liver biopsy corroborated the diagnosis of toxic hepatitis overlapping chronic liver disease. VDZ was withdrawn and the patient experienced complete recovery of liver tests over the following weeks. In this case report, we present the first post-marketing case of hepatocellular liver injury in probable relation to VDZ. @ 2020 Sociedade Portuguesa de Gastrenterologia Published by S. Karger AG, Basel

\section{Hepatotoxicidade induzida pelo Vedolizumab}

Palavras Chave

Vedolizumab · Lesão hepática aguda · Hepatotoxicidade . Lesão hepática induzida por fármacos · Doença inflamatória intestinal

\section{Resumo}

A hepatotoxicidade induzida por fármacos é uma causa importante de lesão hepática aguda. As terapêuticas imunomoduladoras, como o vedolizumab (VDZ), são cada vez mais utilizadas para o tratamento de diversas patologias, particularmente a doença inflamatória do intestino. Vários estudos comprovaram o perfil de segurança favorável do VDZ. Até à data, apenas foi relatado um caso de hepatotoxicidade atribuída ao VDZ em estudos de farmacovigilância pós comercialização. Os autores apresentam o caso de uma mulher de 41 anos, seguida em Gastrenterologia por colite ulcerosa (CU) e hepatite autoimune (HAl). A doença hepática desta doente encontrava-se eficaz- karger@karger.com www.karger.com/pjg

Karger ${ }^{\prime \prime}$ -

BOPEN ACCESS
(C) 2020 Sociedade Portuguesa de Gastrenterologia Published by S. Karger AG, Basel

This article is licensed under the Creative Commons AttributionNonCommercial-NoDerivatives 4.0 International License (CC BY NC-ND) (http://www.karger.com/Services/OpenAccessLicense). Usage and distribution for commercial purposes as well as any distribution of modified material requires written permission.
Miguel Mascarenhas Saraiva

Gastroenterology Department

Centro Hospitalar Universitário de São João

Rua Oliveira Martins 104, PT-4200-427 Porto (Portugal)

miguelmascarenhassaraiva @ gmail.com 
mente controlada com corticoterapia em baixa dose (prednisolona $10 \mathrm{mg}$ ). Concomitantemente, a terapêutica dirigida à CU incluía salicilatos (messalazina $3 \mathrm{~g} / \mathrm{dia}$ ) e budesonido ( $9 \mathrm{mg} / \mathrm{dia}$ ) orais. Por apresentar CU não controlada com o esquema referido, iniciou VDZ. Duas semanas após a primeira infusão de VDZ, a doente desenvolve manifestações clínicas e analíticas compatíveis com quadro de hepatite. Do estudo etiológico realizado, nenhuma causa foi identificada como responsável pela lesão hepatocelular. Foi realizada uma biópsia hepática que corroborou o diagnóstico de hepatite tóxica a sobreporse a características de doença hepática crónica. A terapêutica com VDZ foi interrompida e a doente apresentou recuperação de valores normais do perfil hepático durante as semanas que se sucederam. Com este trabalho, os autores expõem o primeiro caso pós-comercialização de lesão hepatocelular em provável relação com VDZ.

C 2020 Sociedade Portuguesa de Gastrenterologia Publicado por S. Karger AG, Basel

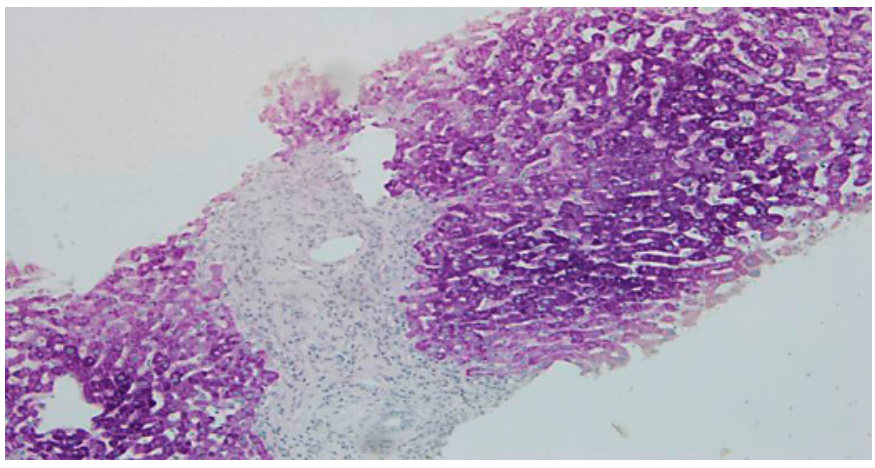

Fig. 1. Hematoxylin-eosin stain $(\times 100)$ showing portal tracts expansion with polymorphic inflammatory infiltrate constituted by lymphocytes, plasma cells and eosinophils and low-density fibrosis.

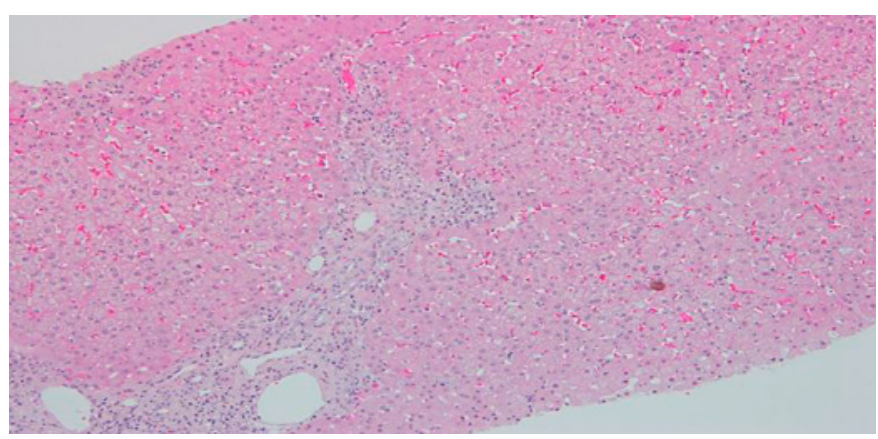

Fig. 2. Hematoxylin-eosin stain $(\times 100)$. Multifocal intralobular necroinflammatory lesions, with rare foci of confluent necrosis. Small aggregates of macrophages revealing previous necroinflammatory activity.

ten, evidence is gathered through retrospective post-marketing pharmacovigilance studies [1]. The diagnosis of DILI requires the identification of a potential causative agent and exclusion of other forms of liver injury. That identification may be difficult, particularly in polymedicated patients. Although DILI is the most common cause of acute liver failure in the Western hemisphere, most cases are self-limited, resolving upon withdrawal of the trigger [2, 3].

Vedolizumab (VDZ) is a humanized antibody directed at $\alpha 4 \beta 7$ integrin. Inhibition of the interaction between this protein and mucosal vascular addressin cell adhesion molecule 1 (MaDCAM-1), hampers the migration of guthoming CD4+ T lymphocytes, thus providing gut-selective immunosuppression. The effectiveness of VDZ has been proved in both clinical trials and real-world experiments, and it is approved for inductive and maintenance treatment of moderate-to-severe ulcerative colitis (UC) and Crohn's disease $[4,5]$. As far as the authors knowledge goes, there has only been one post-marketing case report of severe hepatoxicity attributable to VDZ [6].
Herein, we present the case of a patient presenting with acute hepatocellular pattern of liver injury probably related to VDZ.

\section{Case Presentation}

The authors present the case of a 41-year-old female followed at the gastroenterology outpatient clinic for UC diagnosed 11 years earlier, under treatment with oral salicylates (mesalamine $3 \mathrm{~g} /$ day) and oral budesonide $(9 \mathrm{mg} /$ day). Moreover, her medical record was remarkable for autoimmune hepatitis ( $\mathrm{AIH})$, diagnosed at the age of 31 years. Besides altered liver tests, she had increased IgG levels and positive anti-smooth muscle antibodies. Biopsy revealed lymphoplasmacytic portal tract expansion and centrolobular necroinflammatory lesions, as well as F2 stage of fibrosis (Fig. 1, 2). Pretreatment calculation of the revised original AIH score resulted in the diagnosis of definite AIH (score 20). Autoimmune hepatitis was first treated with budesonide; later the patient was 
Table 1. Results of the etiologic workup upon admission

\begin{tabular}{|c|c|c|c|c|}
\hline Liver tests (units) [normal range] & $\begin{array}{l}\text { Before } \\
\text { VDZ start }\end{array}$ & Admission & Discharge & $\begin{array}{l}9 \text { weeks } \\
\text { after VDZ } \\
\text { start }\end{array}$ \\
\hline $\operatorname{AST}(\mathrm{U} / \mathrm{L})[10-31]$ & 19 & 667 & 454 & 27 \\
\hline $\operatorname{ALT}(\mathrm{U} / \mathrm{L})[10-31]$ & 9 & 1,061 & 828 & 31 \\
\hline Alkaline phosphatase (U/L) [30-120] & & 102 & 95 & 49 \\
\hline$\gamma$-GT $(\mathrm{U} / \mathrm{L})[7-32]$ & & 143 & 119 & \\
\hline Total bilirubin $(\mathrm{mg} / \mathrm{dL})[<1.20]$ & 0.65 & 3.02 & 2.82 & 0.86 \\
\hline Conjugated bilirubin $(\mathrm{mg} / \mathrm{dL})[<0.40]$ & 0.15 & 1.99 & & 0.21 \\
\hline Albumin $(\mathrm{g} / \mathrm{L})[38.0-51.0]$ & 38.5 & & & 44.2 \\
\hline INR & & 1.11 & & \\
\hline $\mathrm{R}$ factor & & 31.2 & & \\
\hline $\operatorname{IgG}(\mathrm{mg} / \mathrm{dL})[650-1,500]$ & & 1,440 & & \\
\hline ANA $[<1 / 100]$ & & $>1 / 1,000$ & & \\
\hline Anti-dsDNA (IU/mL) $[<100.0]$ & & $<10.0$ & & \\
\hline Anti-LKM & & Negative & & \\
\hline AMA & & Negative & & \\
\hline ASMA & & Negative & & \\
\hline Anti-HCV & & Negative & & \\
\hline $\mathrm{HCV}$ - RNA & & Negative & & \\
\hline HBV - AgHBs/Anti-HBc/Anti-HBs & & $(-/-/+)$ & & \\
\hline $\mathrm{HAV}-\mathrm{IgM} / \mathrm{IgG}$ & & $(-1-)$ & & \\
\hline $\mathrm{HEV}$ - RNA & & Negative & & \\
\hline HSV - IgM/IgG & & $-1+$ & & \\
\hline CMV - Biopsy/IgM/IgG & & $-1-1-$ & & \\
\hline $\mathrm{EBV}-\mathrm{IgM} / \mathrm{IgG}$ & & $-1+$ & & \\
\hline
\end{tabular}

Baseline values of liver enzymes (before VDZ) and evolution after withdrawal are also presented. ALT, alanine aminotransferase; AMAs, anti-mitochondrial antibody; ANA, anti-nuclear antibody; ASMA, anti-smooth muscle antibody; AST, aspartate aminotransferase; CMV, cytomegalovirus; dsDNA, double-strand DNA; EBV, Epstein-Barr virus; $\mathrm{HAV}$, hepatitis A virus; $\mathrm{HBV}$, hepatitis B virus; $\mathrm{HCV}$, hepatitis $\mathrm{C}$ virus; $\mathrm{HEV}$, hepatitis $\mathrm{E}$ virus; HSV, Herpes simplex virus; INR, International Normalized Ratio; LKM, Liver-kidney microsome; $\gamma$-GT, gammaglutamyltranferase.

started on glucocorticoids and azathioprine - the latter was withdrawn due to severe marrow suppression, and she remained effectively controlled with $10 \mathrm{mg}$ of prednisolone. Additionally, she was taking lisinopril and simvastatin for hypertension and dyslipidemia, respectively. VDZ was added to her therapeutic scheme for UC because of frequent exacerbations under her previous treatment. She received two doses of VDZ on week 0 and 2. One day after the second dose, the patient presented to the emergency department with new-onset fatigue and painless jaundice. Beside jaundice, her physical examination was unremarkable. Laboratory results revealed elevated hepatic enzymes displaying a pattern of hepatocellular lesion (ALT elevated more than 30 times the upper level of normal; calculated R factor: 31.2; total bilirubin of $3.02 \mathrm{mg} /$ $\mathrm{dL}$ ). Pretreatment liver tests before starting VDZ were normal (Table 1). The patient was hospitalized for further diagnostic workup. She denied alcohol intake, drug abuse, use of herbal supplements or other over-the-counter drugs, recent travels, or high-risk sexual behaviors. Viral markers and autoimmune profile returned negative results (Table 1). Abdominal ultrasonography described hepatomegaly. At this point, the hypothesis of toxic hepatitis through
VDZ-induced liver injury was deemed probable, attending to the chronologic sequence and absence of other apparent etiologies upon investigation. A percutaneous liver biopsy was then performed, demonstrating features of acute hepatitis overlapping chronic hepatitis, with centrolobular necroinflammatory activity, lymphoplasmacytic inflammatory infiltrate and moderate fibrosis (Fig. 3, 4), agreeing with the hypothesis of VDZ-induced acute hepatitis overlapping chronic autoimmune hepatitis. Causality was assessed through the application of the Council for International Organization of Medical Sciences (CIOMS) scale [7]; a score of 6 was obtained, compatible with probable relation between VDZ and hepatocellular damage (Table 2). The patient's clinical evolution was favorable, and she was discharged 3 days after admission. VDZ was withdrawn after the two doses. No other changes were introduced to the patient's usual medication. Subsequent repetition of liver tests exhibited normalization of aminotransferases over the following weeks (Fig. 5). The patient had no new UC flares, and endoscopic reevaluation 11 weeks after VDZ withdrawal revealed remitting UC. 


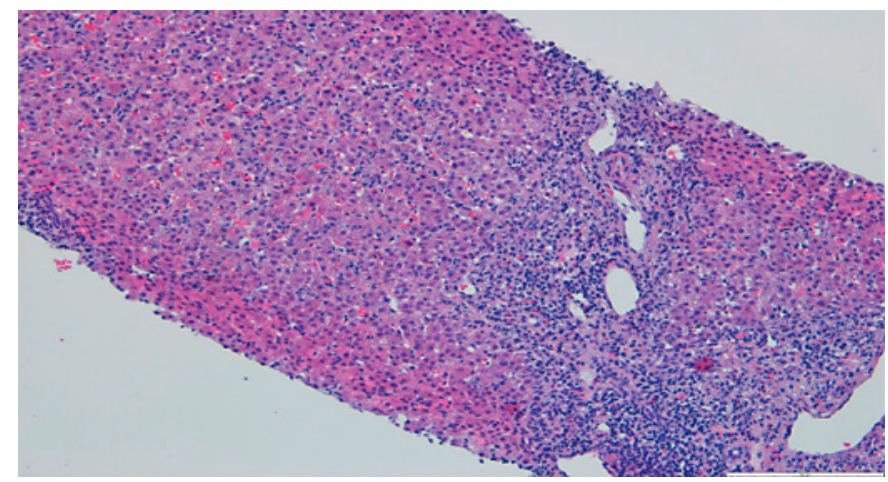

Fig. 3. Hematoxylin-eosin stain $(\times 100)$ showing moderate fibrosis of portal tracts, with a polymorphic inflammatory infiltrate constituted by lymphocytes, plasma cells and eosinophils.

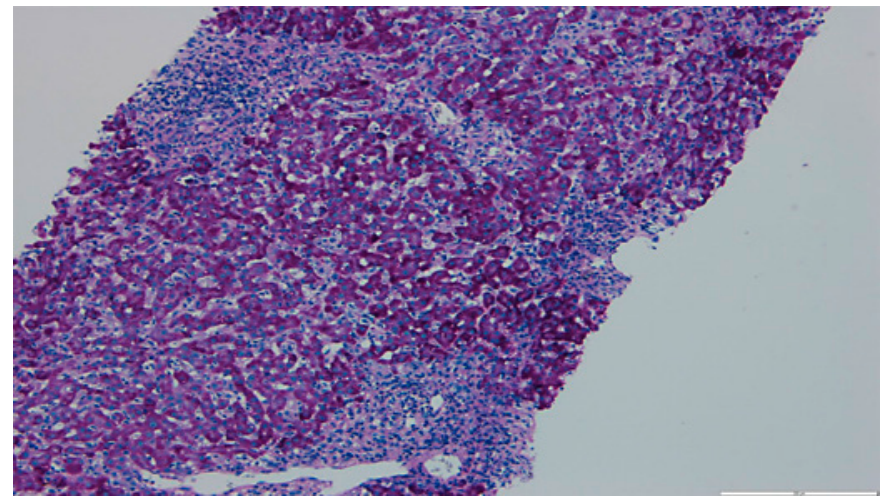

Fig. 4. Hematoxylin-eosin stain $(\times 100)$ displaying parenchymal disarray, with swollen Kupffer cells and centrolobular necroinflammatory lesions. Some acidophil bodies are also seen.
Fig. 5. Evolution of alanine aminotransferase (ALT), total bilirubin (TB) and alkaline phosphatase (Alk $\mathrm{P}$ ) in relation to first VDZ infusion ( $t=0$ days). Days counted as negative numbers relate to a timepoint before the first infusion.

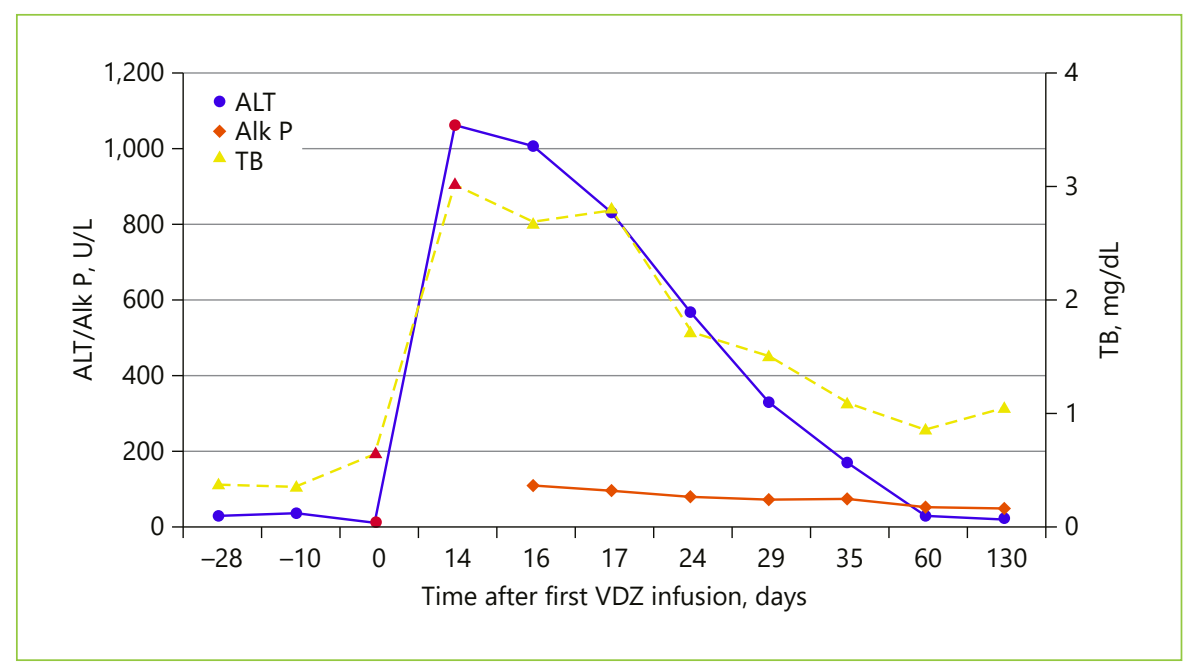

\section{Discussion/Conclusion}

The case reported in this study constitutes, to the best knowledge of the authors, the first post-marketing case of a pattern of hepatocellular injury with probable relation to treatment with VDZ. The chronological relationship between the beginning of VDZ and the onset of hepatitis symptoms heightened our level of suspicion. Furthermore, an extensive workup for other causes of hepatocellular damage was undertaken and retrieved negative results, particularly viral markers, and autoimmune study (Table 1).

An important differential diagnosis to consider in this case was a flare of previously diagnosed AIH. Several factors pointed towards hepatotoxicity to VDZ instead of AIH: the patient had a clinically stable AIH controlled with a low dosage of prednisolone; the onset of liver test abnormalities after VDZ initiation; the patient was kept on her usual dosage of glucocorticoid, with complete normalization of liver tests upon withdrawal of the immunomodulatory therapy (Fig. 5). To further clarify our clinical suspicion, a liver biopsy was performed according to the recommendations of the European Association for the Study of the Liver (EASL) [1]. The biopsy revealed morphologic aspects of acute hepatitis caused by probable toxic insult, overlapping features of chronic liver disease. This case illustrates the importance of biopsy in the etiologic investigation of suspected toxic hepatocellular damage.

VDZ was the first gut-selective agent approved for the treatment of inflammatory bowel disease. Data regarding safety of VDZ collected from prelicensure phase 2 and 3 clinical trials report a lower adjusted incidence of adverse events (AEs) in VDZ-treated patients [8]. It is approved as a first-line biological therapy in UC [5]. Severe AEs occur in approximately $8 \%$ of the VDZ-exposed patients, 
Table 2. Council for International Organizations of Medical Sciences (CIOMS) causality assessment scale ${ }^{1}$ (adapted from Danan et al. [7])

CIOMS/Roussel Uclaf Causality assessment method scoring

Hepatocellular type reaction

\section{Time to onset}

From the start of the drug

Suggestive

Compatible

\section{Course}

After cessation of the drug

Highly suggestive

Suggestive

Compatible

Inconclusive

Against the role of the drug

\section{Risk factors}

Alcohol

Absence

$\geq 55$ years

$<55$ years

Age
Difference between peak ALT and ULN

Decrease $\geq 50 \%$ within 8 days +3

Decrease $\geq 50 \%$ within 30 days

No information or decrease $\geq 50 \%$ after the $30^{\text {th }}$ day

\section{Concomitant drugs}

None or no information or concomitant drug with incompatible time of onset

Concomitant drug with compatible or suggestive time to onset

Concomitant drug known as hepatotoxin with a suggestive time to onset

Concomitant drug with evidence for its role in this case

\section{Exclusion of other non-drug causes of acute liver injury}

Group I

Viral hepatitis (HAV, HBV, HCV)

Biliary obstruction

Alcoholism

Recent history of acute hypotension

Group II

Complications of underlying diseases

Acute infection with CMV, EBV, HSV
$+2$

All group I causes ruled out

4 or 5 causes of group I ruled out

0

$<4$ causes of group I ruled out

$-2$

Non-drug cause highly probable

Previous information on hepatotoxicity of the drug

Reaction labelled in the product characteristics

Reaction published but unlabeled

Reaction unknown

\section{Response to readministration}

Positive

Compatible

Negative

Not done or not interpretable

TOTAL

Highly probable (>8); probable (6-8); possible (3-5); unlikely (1-2) $+3$

Doubling of ALT with the drug alone

Doubling of ALT with the drugs present at the time of first reaction Increase of ALT but less than the ULN in the same conditions as for the first reaction -2 Other situations

ALT, alanine aminotransferase; CMV, cytomegalovirus; EBV, Epstein-Barr virus; HAV, hepatitis A virus; HBV, hepatitis B virus; $\mathrm{HCV}$, hepatitis C virus; HSV, Herpes simplex virus; ULN, upper level of normal. ${ }^{1}$ Each score relating to this case is given in bold. 
but only $5 \%$ require withdrawal of the drug. Furthermore, the occurrence of AEs seems to be independent from the duration of exposure. Age-stratified analyses did not show an effect of age in the incidence of significant AEs [9]. The incidence of abnormal liver tests was not significantly different from placebo and did not lead to discontinuation of the drug. Elevation of ALT of more than 5 times the upper level of normal were rare $(<2 \%)$ and occurred in similar frequency as in those under placebo [10]. However, Colombel et al. [8] described three cases of serious liver injury, two of them with probable AIH. Recent works, including data from both trial and postmarketing phases, confirm that hepatobiliary AEs are uncommon $(<1 \%$ of all AEs registered), occurring in up to $5 \%$ of patients, and mostly related to abnormalities in the levels of liver enzymes [11, 12]. Stine et al. [6] reported the first post-marketing case of hepatotoxicity ascribed to the use of VDZ. Their case differed from ours in several aspects: first, their patient presented a cholestatic pattern of liver injury; second, their case presented after the third infusion of VDZ, and opposite to our patient, his symptoms developed later and more insidiously; third, their patient had persistent liver tests abnormalities 5 months after VDZ withdrawal, suggesting progression to chronic DILI. Similar to our report, their patient had a concomitant disease confounding the clinical picture (AIH in our report and primary sclerosing cholangitis in theirs). There was no evidence to support the role of any of these chronic diseases in the liver injury of both cases. Nevertheless, our study was complemented by a biopsy, which corroborated our hypotheses of VDZ-induced DILI.
This case highlights the necessary degree of suspicion for the diagnosis of rare events, such as clinically significant VDZ-induced hepatotoxicity. Moreover, it emphasizes the importance of a complete etiologic workup, particularly the role of liver biopsy, in order to exclude other differential diagnosis.

\section{Statement of Ethics}

All rules of the local Ethics Committee ("Comissão de Ética para a Saúde do Centro Hospitalar de São João/Faculdade de Medicina da Universidade do Porto, Portugal") were followed, preserving patient identity and confidentiality. Informed consent was obtained from the patient for the publication of his case.

\section{Conflict of Interest Statement}

The authors have no conflicts of interest to disclose.

\section{Funding Sources}

The authors declare that there was no source of funding.

\section{Author Contributions}

Miguel Mascarenhas Saraiva: Wrote and revised the manuscript. Tiago Filipe Ribeiro: Wrote and revised the manuscript. Emanuel Dias: Wrote and revised the manuscript. Joanne Lopes: Revised the manuscript. Hélder Cardoso: Revised the manuscript. Guilherme Macedo: Revised the manuscript.

\section{References}

1 Andrade RJ, Aithal GP, Björnsson ES, Kaplowitz N, Kullak-Ublick GA, Larrey D, et al.; European Association for the Study of the Liver. Electronic address: easloffice@easloffice.eu; Clinical Practice Guideline Panel: Chair; Panel members; EASL Governing Board representative. EASL Clinical Practice Guidelines: drug-induced liver injury. J Hepatol. 2019 Jun;70(6):1222-61.

2 Bernal W, Wendon J. Acute liver failure. N Engl J Med. 2013 Dec;369(26):2525-34.

3 Wei G, Bergquist A, Broomé U, Lindgren S, Wallerstedt S, Almer S, et al. Acute liver failure in Sweden: etiology and outcome. J Intern Med. 2007 Sep;262(3):393-401.

4 Torres J, Bonovas S, Doherty G, Kucharzik T, Gisbert JP, Raine T, et al. ECCO Guidelines on Therapeutics in Crohn's Disease: medical Treatment. J Crohn's Colitis. 2020 Jan;14(1):4-22.
5 Harbord M, Eliakim R, Bettenworth D, Karmiris K, Katsanos K, Kopylov U, et al.; European Crohn's and Colitis Organisation [ECCO]. Third European Evidence-based Consensus on Diagnosis and Management of Ulcerative Colitis. Part 2: current Management. J Crohn's Colitis. 2017 Jul;11(7):769-84.

6 Stine JG, Wang J, Behm BW. Chronic Cholestatic Liver Injury Attributable to Vedolizumab. J Clin Transl Hepatol. 2016 Sep;4(3):277-80.

7 Danan G, Benichou C. Causality assessment of adverse reactions to drugs-I. A novel method based on the conclusions of international consensus meetings: application to drug-induced liver injuries. J Clin Epidemiol. 1993 Nov;46(11):1323-30.

8 Colombel JF, Sands BE, Rutgeerts P, Sandborn W, Danese S, D'Haens G, et al. The safety of vedolizumab for ulcerative colitis and Crohn's disease. Gut. 2017 May;66(5):83951.
9 Yajnik V, Khan N, Dubinsky M, Axler J, James A, Abhyankar B, et al. Efficacy and Safety of Vedolizumab in Ulcerative Colitis and Crohn's Disease Patients Stratified by Age. Adv Ther. 2017 Feb;34(2):542-59.

10 Vedolizumab (Entyvio) for inflammatory bowel disease. Med Lett Drugs Ther. 2014 Sep;56(1451):86-8.

11 Cohen RD, Bhayat F, Blake A, Travis S. The Safety Profile of Vedolizumab in Ulcerative Colitis and Crohn's Disease: 4 Years of Global Post-marketing Data. J Crohn's Colitis. 2020 Feb;14(2):192-204.

12 Vermeire S, Colombel JF, Feagan BG, Sandborn WJ, Sands BE, Danese S, et al. OP26 Long-term safety of vedolizumab in ulcerative colitis and Crohn's disease: final results from the GEMINI LTS study. J Crohn's Colitis. 2019;13 Supplement_1:S018-020. 